RTDF2008-74026

\title{
EVALUATION OF OCCUPANT VOLUME STRENGTH IN CONVENTIONAL PASSENGER RAILROAD EQUIPMENT
}

\author{
Michael Carolan \\ Benjamin Perlman \\ David Tyrell \\ U.S. Department of Transportation \\ Volpe National Transportation Systems Center \\ Cambridge, Massachusetts
}

\begin{abstract}
To ensure a level of occupant volume protection, passenger railway equipment operating on mainline railroads in the United States must be designed to resist an 800,000-lb compressive load applied statically along the line of draft. An alternative manner of evaluating the strength of the occupied volume is sought, which will ensure the same level of protection for occupants of the equipment as the current test, but will allow for a greater variety of equipment to be evaluated.

A finite element (FE) model of the structural components of a railcar has been applied to examine the existing compressive strength test and evaluate selected alternate testing scenarios. Using simplified geometric and material properties, a generic single-level railcar model was constructed that captured the gross behaviors of the railcar without excessive processing time.

When loaded, the carbody structure exhibits some single beam-like behaviors. Application of the existing 800 kip compressive load results in a significant bending moment as well as significant compressive forces. The alternative load cases examined show that a larger total compressive force may be distributed across the end structure of the railcar and result in similar stress levels throughout the structural frame as observed from application of the conventional proof load.
\end{abstract}

\section{INTRODUCTION}

This investigation set out to examine the demands placed on the carbody by the currently prescribed compressive strength test. Results are then used to examine alternative loading conditions that provide equivalent stress states. These alternative load cases could generate similar behavior in the railcar without requiring particular construction details to be present in the vehicle.
In the United States, intercity, passenger, and freight rail operations are regulated by the Federal Railroad Administration (FRA), within the Department of Transportation (DOT) [1]. While rail travel is a safe form of transportation, it is important that passenger railcars be designed to incorporate features that preserve survival space for occupants to "ride out" the collision in the rare event of an accident.

The construction requirement that most influences the strength of a passenger railcar is known as the "Static End Strength Requirement," located in the Code of Federal Regulations (CFR) at 49CFR238.203 [2]. This requirement states, in part, that "all passenger equipment shall resist a minimum static end load of 800,000 pounds applied on the line of draft without permanent deformation of the body structure."

While "line of draft" is not explicitly defined within the Static End Strength Requirement, this term has historically referred to the line of action connecting the two couplers of the railcar. The line of draft is a concept, as there is no physical member running in a straight line between the two couplers in a railcar of conventional construction. The line is shown on a schematic railcar in Figure 1.

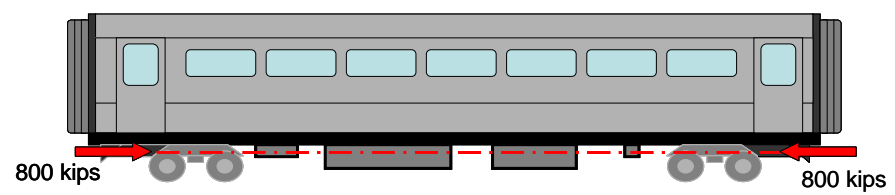

Figure 1 - Line of Draft on Conventional Railcar

During the actual proof test, the load is reacted against the buff stops, within the draft sill. This places the load inboard of the endframe of the car, and places the line of draft below the underframe. This load is shown schematically in Figure 2. 


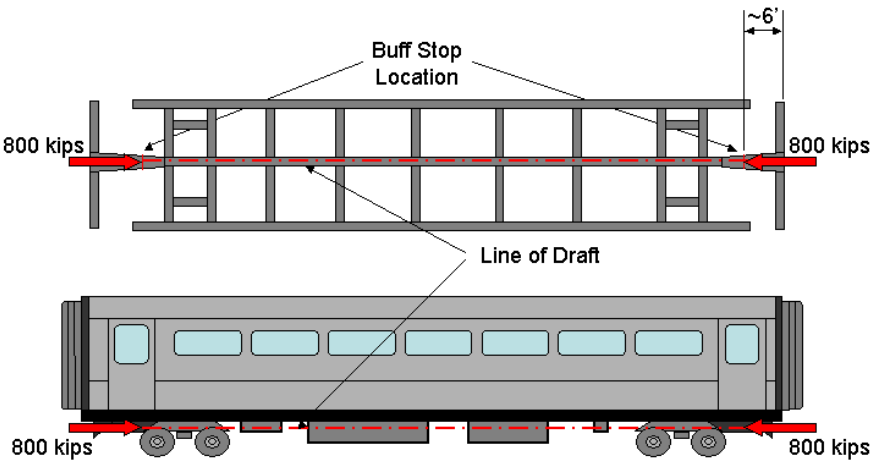

Figure 2 - Schematic Application of Compressive
Strength Test, Conventional Railcar

The compressive strength requirement typically results in a railcar with a strong underframe but a considerably less strong superstructure. Additionally, the ability to pass this test has heavily shaped the design of passenger railway equipment for domestic service, so that railcars from different eras and different manufacturers share a similar structure to one another. Even in car designs that feature multiple levels, the center sill is typically the dominant longitudinal member, with the underframe designed to meet the 800 kip requirement.

Difficulty arises when a railcar that does not feature conventional construction attempts to qualify with the compressive strength test. As an example, vehicles in service outside of the United States may feature coupling mechanisms at different heights at each end of the car. The line of draft is less easily defined in this type of vehicle. Application of an 800 kip compressive load to structures at different heights may result in an undesirable pitching moment in the railcar. The compressive load is shown schematically applied to an articulated vehicle in Figure 3, where the pitch of the car is exaggerated.

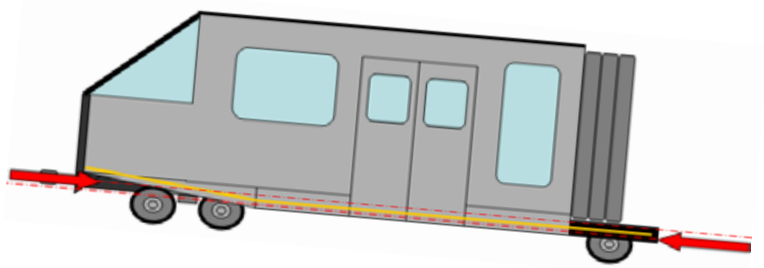

\section{Figure 3 - Compressive Load Applied to Articulated Railcar}

One option is the development of an alternative requirement that may be applied in place of the 800 kip test. A load or series of loads that assess the occupant volume's compressive strength and resistance to bending could be developed that make use of the available structure at the extreme ends of the railcar. The loads applied to opposite ends of a car could be chosen strategically to prevent gross motions of the car. By providing an alternative loading condition, manufacturers would have the option of evaluating the railcar under either the 800-kip test or the alternative load conditions.

\section{Existing 800 kip Load}

It is important to first consider the existing proof load and its benefits before developing alternative loads. Regardless of the proof load a vehicle is designed to, occupants should be afforded equivalent levels of protection. Any alternative load should also ensure that compatibility of equipment is maintained, such that in an accident involving equipment designed to the "traditional" 800-kip load and the alternative load, both types of vehicle provide equivalent protection to their occupants.

One reason for the widespread adoption of the 800-kip load is its straightforward application and analysis. This test requires a test article, ballasting material, load cells capable of measuring 800,000 lb, and a testing frame capable of generating the necessary compressive loads. Instrumentation is fairly straightforward, with strain gages placed at critical areas on the railcar body. Displacement transducers may also be used to measure deflections of the carbody during the test.

The criterion for passing this test is no permanent deformation of the carbody, which may be verified both by instrumentation and by visual inspection. This makes the 800kip compressive strength test a nondestructive test for a welldesigned test article. The importance of this aspect of the test cannot be overlooked, as a small number of passenger railcars are constructed in a given year, at a significant cost per vehicle [3]. Any alternative test proposed must possess equally desirable instrumentation, verification, and nondestructive properties if it is to be acceptable to the railroad industry.

\section{History of Compressive Strength Requirements}

While the equipment and operating environment found on a modern passenger railroad differ from the railroads of the early $20^{\text {th }}$ century, the potential hazards faced by the railroads are similar. All railroad cars need to protect the occupants not just from the exterior environment during normal operations, but also during collisions and other accidents.

Some of the earliest steel passenger railcars in the United States were developed by the Pennsylvania Railroad in 1906. These cars were designed to "withstand... a minimum end force of 200 tons" [4]. It is unclear how this value was chosen as the basis for longitudinal strength.

At the same time, the United States Post Office had a number of Railway Post Office (RPO) cars in operation across the country [5]. These cars acted as mobile post offices, where clerks processed mail while the train was en route to its destination. In response to a number of fatal collisions involving RPO cars, the Post Office issued its Railway Mail Service (RMS) Specification for the construction of RPO cars in 1912 [6]. This specification originally required cars to resist a 400,000-lb compressive load in the underframe; later revisions included a factor of safety of 2 , bringing the effective load up to $800,000 \mathrm{lb}$ [7]. 
While the specification was only applied to RPO cars, railroads began incorporating elements from it into their own procurement specifications. In the 1930's, concerns were raised that "lightweight" and "heavyweight" steel passenger cars were incompatible with one another when involved in accidents [4]. In 1939, the Association of American Railroads (AAR) developed recommended practices for the design of passenger cars which included a number of features from the RMS specification. In 1945, the recommended practices were adopted into an AAR standard, "Specifications for the Construction of New Passenger Equipment Cars," (S-034) with the strength requirement being an 800,000-lb load applied on the center line of draft with no permanent deformation in the car structure [8]. This standard also included requirements for the carbody to meet 500,000 lb applied at the center of the buffer beam, and 400,000 lb between the buffer beam and the line of draft [9].

In 1956, multiple-unit (MU) locomotives were required to meet the 800,000-lb compressive strength requirement [6]. This regulation can currently be found at 49CFR229.141. In 1989, the AAR discontinued publication of its standard S-034, though the standard was still used by operators and manufacturers. In 1999, the FRA issued its passenger rail equipment safety standards, found at 49CFR238, making the 800-kip compressive strength test a legal requirement for all passenger equipment operating within FRA's jurisdiction.

Also in 1999, the American Public Transportation Association (APTA) approved "Standard for the Design and Construction of Passenger Railroad Rolling Stock," SS-C\&S034-99 [10]. This standard includes requirements for meeting both an 800-kip load applied on the line of draft and a 500-kip compressive load applied over a section of the underframe end member or buffer beam.

\section{MODELING APPROACH}

Previous railroad crashworthiness research performed by DOT has resulted in the creation of a number of finite element models with high levels of structural fidelity. These models have been designed to simulate dynamic crash events, and feature complex material behavior, highly-refined meshes, and detailed connections. An overview of these models is provided in reference 11 .

The 800-kip compressive strength test requires a passenger car to be able to resist a quasi-static load without experiencing permanent deformation. While the existing, detailed models would be capable of simulating the buff strength test, a better approach is to construct a new, simplified model for just that purpose. Since it is unknown what alternative tests will give similar results to the 800-kip test, it is likely a number of simulations will be needed, preferably with a reasonably small processing time.

Typically, single-level passenger railcars feature a center sill and two side sills as the longitudinal members of the underframe, with lateral cross members tying these three members together. The superstructure is composed of a number of longerans with significantly smaller cross-sectional areas, tied together by vertical wall stiffeners and the wall panels themselves. A conventional single-level passenger railcar with key longitudinal members highlighted is shown in Figure 4. While not included in this particular railcar, longitudinal members, known as purlins, support the roof near the centerline of the car in some other designs.

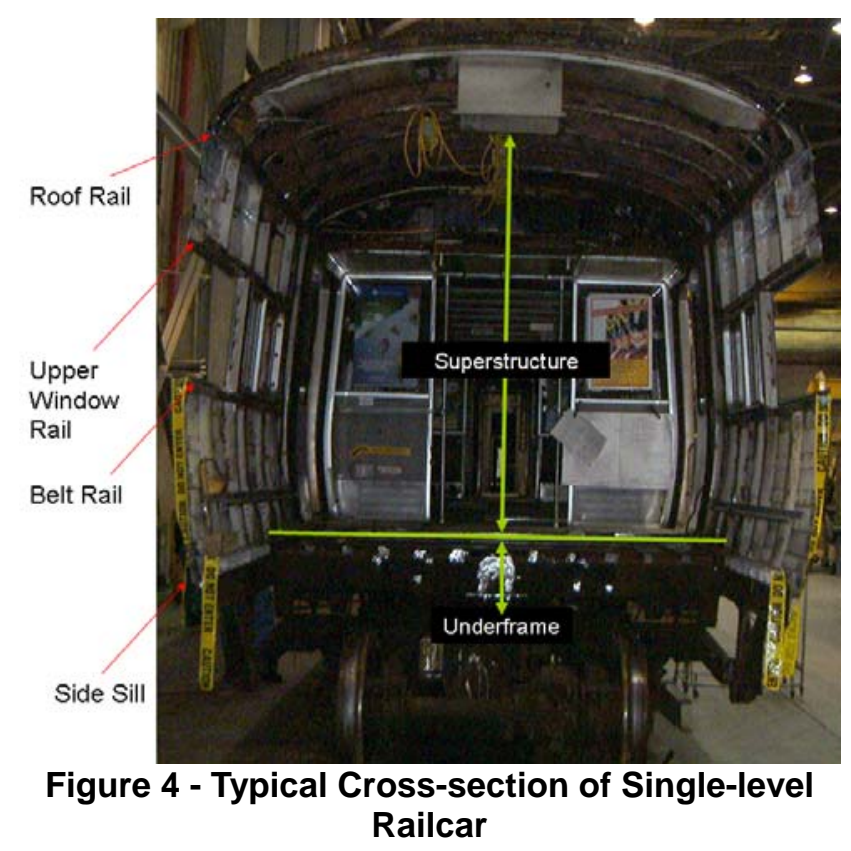

Because the structural frame of the car is what is resisting this load, it is not necessary to include features such as couplers, trucks, or interior fixtures in a simulation of this test. Additionally, the materials used in the structure of the car can be maintained as linear elastic, since a car that passes the compressive strength test experiences no permanent deformation. These simplifications result in a model with a runtime on the order of minutes.

Technical drawings from railcar manufacturers, previous finite-element models, and photographs of equipment were all utilized in the construction of the model. While sufficient information existed to construct a simplified model of a particular type of car, the purpose of this research was to evaluate the test, not the car undergoing the test. Details in member geometry unique to a particular car design were simplified in the modeling. Because conventionally-designed passenger railcars share a number of common construction elements, the finite element (FE) model developed is referred to as a "generic" single-level passenger car model.

The commercial software ABAQUS/CAE was used in the construction of this model [12]. Discrete parts were attached to one another via tied constraints, which simulate perfectly welded connections between corresponding nodes on adjacent parts. Linear springs were used to model the secondary suspension of the car, which allowed the model to lift or lower at the bolsters in response to the loads applied. 
The railcar was constructed using shell elements to mesh the longitudinal, vertical, and lateral members. Additionally, shell elements were used to model the outer skin, roof, and floor of the car. The car was meshed using S4 elements for the structure and Spring1 elements for the suspension. A total of 79,796 elements are used in this model. The characteristic element length is 2.75 inches. The railcar model is shown in Figure 5, with overall dimensions indicated.

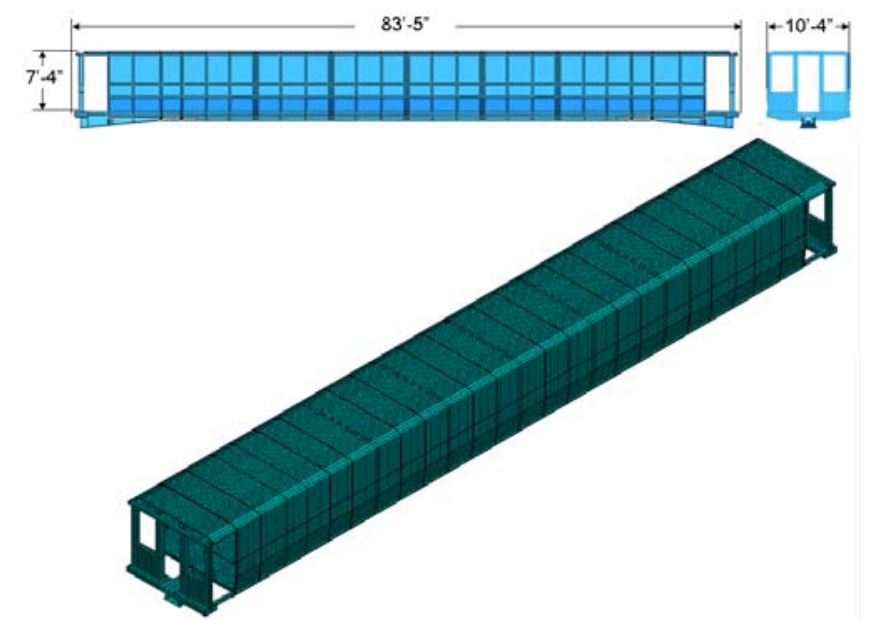

Figure 5 - FE Model Geometry

Because the buff stops can potentially be located inboard of the occupant volume, the entire volume is not being evaluated. The endframe of the car was selected as a potential location to apply alternative loads, as it is a significant structure that is located at the extreme ends of the car. The generic railcar was modeled with a state-of-the-art (SOA) endframe, as well as continuous side sills. The endframe was chosen for its compliance with the most recent industry standards [13]. A SOA endframe is shown in Figure 6, with key structures indicated.

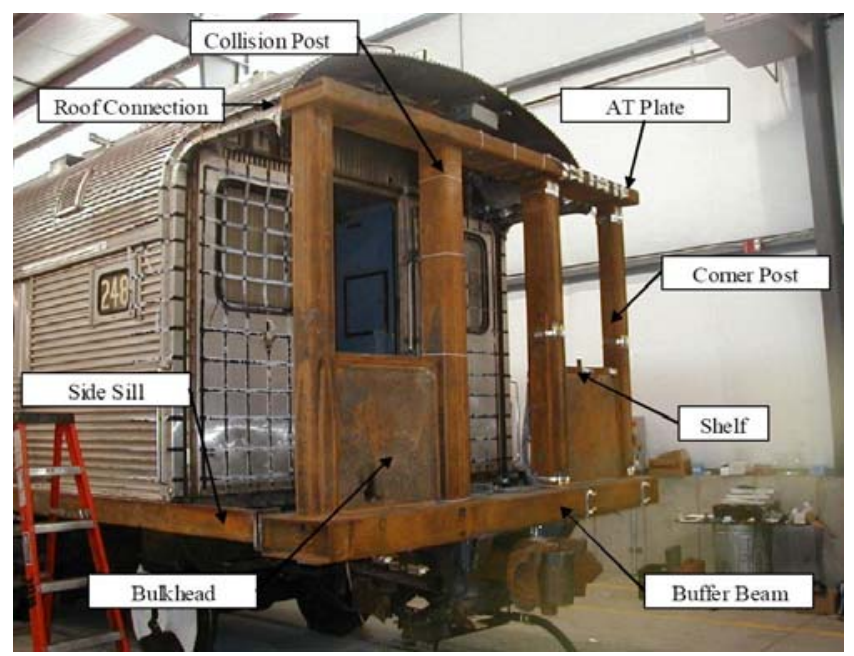

Figure 6 - SOA Endframe

\section{$\underline{\text { Railcar Properties }}$}

As prescribed in APTA SS-C\&S-034-99, the test article subjected to the 800-kip compressive strength test is to be ballasted to its empty, ready-to-run (AW0) weight before the load is applied [10]. The weights of the carbody, the trucks, and the AW0 carbody are provided in Table 1 for the FE model and exemplar conventional passenger railcars.

Table 1 - FE Model Weights

\begin{tabular}{|c|c|c|}
\hline & $\begin{array}{c}\text { FE Model } \\
\text { Weight (lbs) }\end{array}$ & $\begin{array}{c}\text { Actual Railcar } \\
\text { Weight (lbs) }\end{array}$ \\
\hline $\begin{array}{c}\text { Structural } \\
\text { Carbody }\end{array}$ & 21,290 & $24,000[14]$ \\
\hline Trucks (each) & 13,700 & $13,700[4]$ \\
\hline AW0 & 102,380 & $100,000[14]$ \\
\hline AW0, no trucks & 74,980 & 72,600 \\
\hline
\end{tabular}

Since the generic FE model does not include detailed trucks and suspension, it is assumed the trucks weigh the same as in an actual railcar. To account for the equipment on the railcar that does not contribute to the structure of the car but contributes to the weight of the car, the gravitational acceleration value was increased to bring the AW0 weight of the model car in close approximation of an actual railcar.

While a typical railcar of conventional construction includes a number of construction materials, the structural members are nearly all steels. Since the model featured only linear elastic behavior, one steel material was used for the entire structure. Typical values of yield stress for different structural members are provided in Table 2. While plastic behavior is not included in the FE model, the values of stress obtained by the model could be compared to the theoretical yield stress to evaluate how close a member is to yield.

\section{Table 2 - Typical Yield Stresses for Railcar Steels}

\begin{tabular}{|l|c|c|}
\hline \multicolumn{1}{|c|}{ Member } & $\begin{array}{c}\text { Yield Stress } \\
\text { (ksi) }\end{array}$ & $\begin{array}{c}\text { Yield Stress } \\
\text { (MPa) }\end{array}$ \\
\hline $\begin{array}{l}\text { Belt Rail, Roof Rail, } \\
\text { Upper Window Rail }\end{array}$ & 110 & 760 \\
\hline Body Bolster & 65 & 450 \\
\hline Center Sill & 100 & 690 \\
\hline Cross Bearer & 75 & 520 \\
\hline Draft Sill & 100 & 690 \\
\hline Endframe & 75 & 520 \\
\hline Floor Stiffeners & 110 & 760 \\
\hline Floor Pans & 32 & 220 \\
\hline Outer Skin & 50 & 345 \\
\hline Roof Stiffeners & 110 & 760 \\
\hline Side Sills & 75 & 520 \\
\hline Wall Stiffeners & 110 & 760 \\
\hline
\end{tabular}




\section{Carbody Neutral Axis}

Prior to performing the analyses of the car under compressive loading, the neutral axis of the railcar was sought. Treating the carbody as a single beam, one endframe of the carbody was completely fixed while the other end was left free. Gravity was the only load applied to the car, which approximated a cantilevered beam subject to a uniformly distributed transverse load

In a simple beam subject to a transverse load, the transition from positive longitudinal stress to negative longitudinal stress occurs at the neutral axis. Likewise, the element displacement transitions from positive to negative at the neutral axis in the model. Figure 7 shows a contour plot of the longitudinal displacements of the elements in the railcar, with black elements having positive displacement and gray elements having negative displacement.

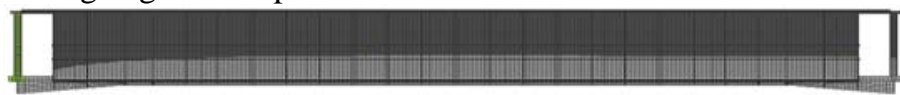

Figure 7 - Contour Plot of Longitudinal Displacement

The longitudinal displacement was investigated along the height of the car wall for various distances from the cantilevered end. The average neutral axis height was found to be approximately 26.5 inches above the floor. The height of transition from positive to negative displacement, for various distances from the cantilevered end, is plotted in Figure 8.

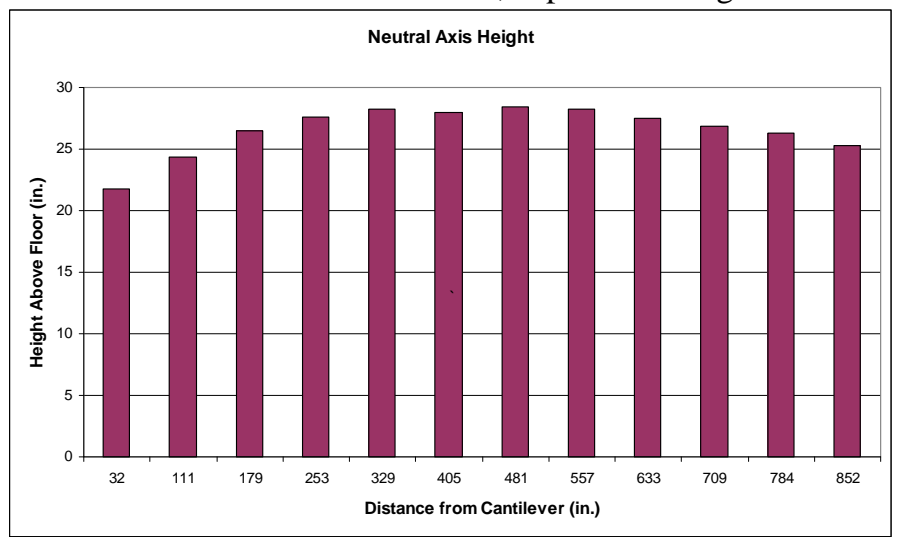

Figure 8 - Neutral Axis Height for Various Crosssections

\section{FINITE ELEMENT RESULTS - CONVENTIONAL TEST}

The railcar was loaded over two static load steps. In the first step, gravity was applied to establish the stress levels present in the standing railcar. In the second step, a compressive load was applied to the car. The conventional, 800 kip load at the buff stops was the first compressive load examined.

\section{Standing Railcar}

During the first step of the analysis, vertical motion of the car is resisted by the linear springs attached at the body bolsters. The lateral motion and longitudinal motions are also prevented, at the same bolster location as the spring attachment. The suspension elements are allowed only vertical motion during the gravity step.

The longitudinal stress was examined in the members running along the length of the occupant volume of the railcar, from body bolster to body bolster. Figure 10 shows the railcar with its external skin removed. The members that are examined in detail are indicated in the callout box.

The members examined generally exhibited low levels of stress across the occupant volume. A plot of the stress distribution across the occupant volume for these members is shown in Figure 9. The periodic peaks in stress correspond to the locations of vertical and lateral members, and the dashed lines indicate the body bolster locations.

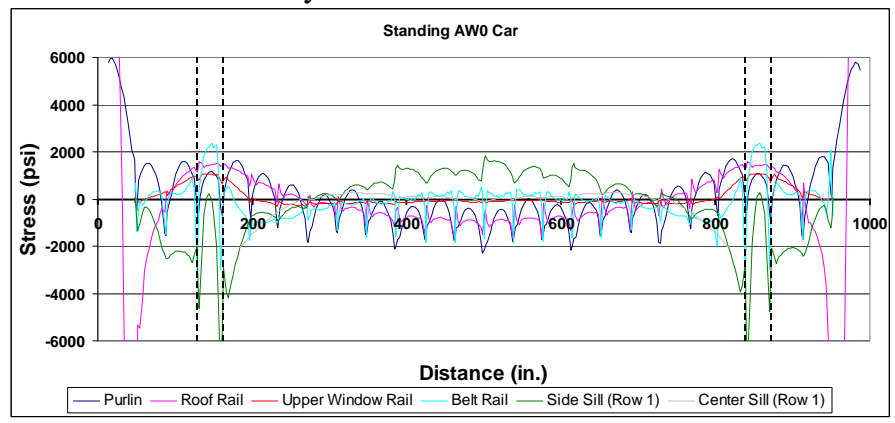

Figure 9 - Stress Distribution in Longitudinal Members Over Occupant Volume, AWO Railcar

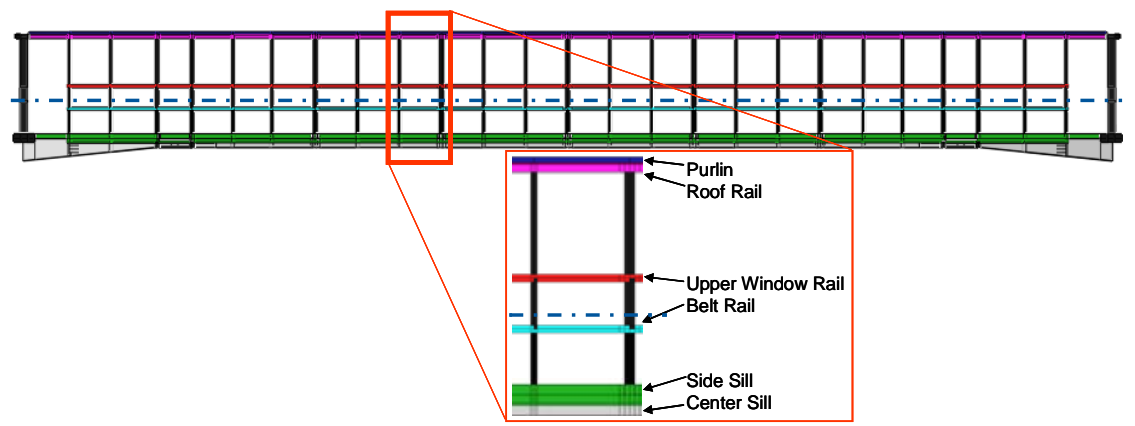

Figure 10 - Longitudinal Members Examined 
In the FE model, the center sill, side sill, and belt rail are located below the neutral axis. The side sill and belt rail both exhibit compressive stresses in the area near the body bolsters and transition to an average tensile stress close to the center of the car. The upper window rail, roof rail, and purlin are all located above the neutral axis. In each of these members, the stresses are tensile near the body bolsters and gradually transition to an average compressive stress toward the center of the car.

This distribution of stress is consistent with the stress distribution seen in a double-overhanging beam with a uniformly applied transverse load. In the case of the FE model, the supports are at the bolsters, in the form of linear springs and boundary conditions. This behavior, plus the neutral axis behavior described in the previous section, gives an indication that the railcar model captures some overall single beam behaviors.

\section{0-kip Compressive Test}

Once the behavior of the railcar under the current load is fully understood, it is possible to investigate alternative load magnitudes and locations. The alternative loads are investigated to determine what, if any, arrangement can result in similar behavior in the railcar body as from the 800-kip test load.

The gravity load from the previous step is maintained during the compression step of the simulation. The boundary conditions are altered during the application of the compressive load. The body bolsters are now allowed motion in the longitudinal direction. Longitudinal motion of the railcar is prevented at the buff stops at the fixed end of the car. The 800kip compressive load is then applied to the buff stops at the opposite end of the car as a uniform pressure load. The load is applied gradually, as is done in the actual test.

Because the buff stops on a conventional passenger railcar are located below the effective neutral axis of the railcar (Figure 7), a compressive load at this location induces a bending moment within the carbody. The longitudinal compressive load will also contribute to the stress state present in the car during this load, adding to the bending moment load below the neutral axis but acting in the opposite direction above the neutral axis. The stress distribution in a beam subject to this type of combined loading is shown in Figure 11, schematically.

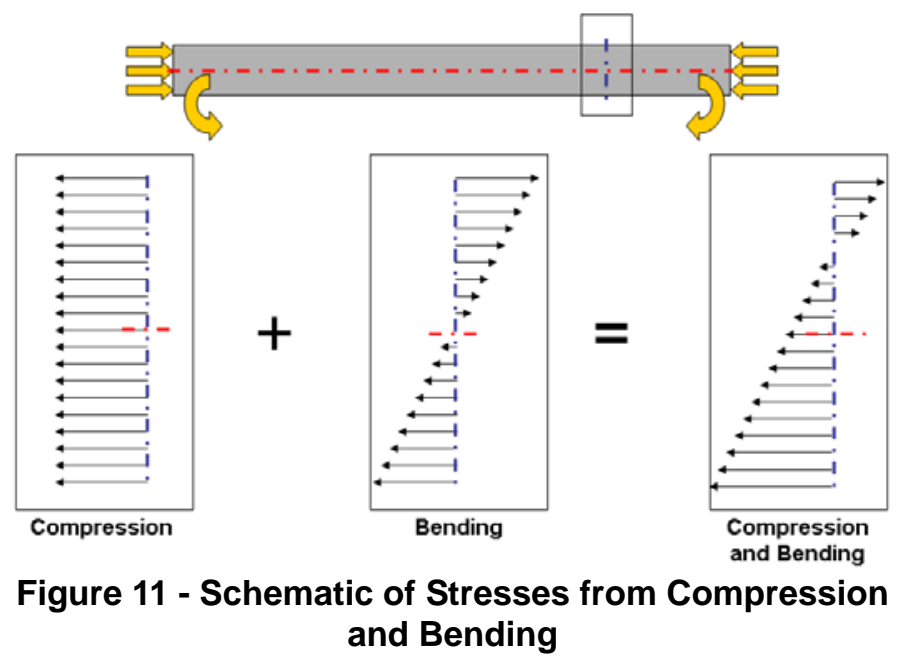

This moment causes the railcar to lift up at the center of the body, while the gravity load causes the center of the car to deflect down. The effect of each load on the carbody is shown in exaggerated schematic form in Figure 12.

Carbody Deformed Shape Gravity Load
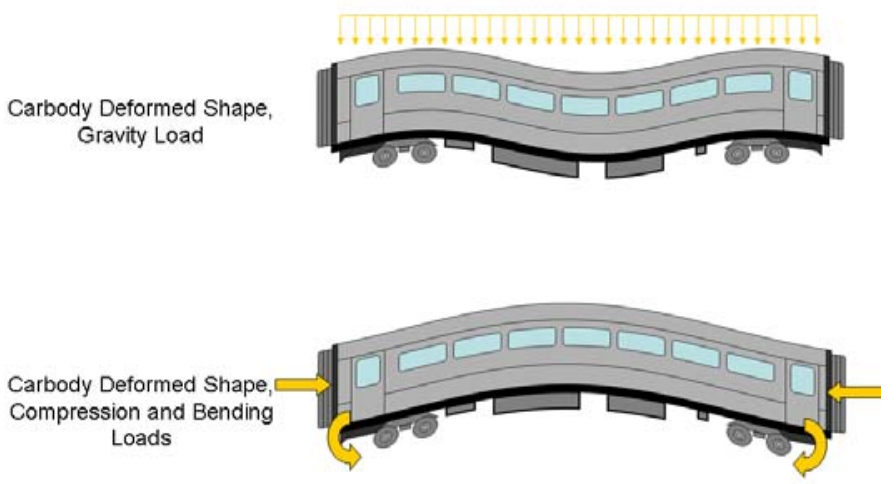

Figure 12 - Exaggeration of Deformation of Carbody Under Gravity and Buff Loads

The longitudinal stress is reported for the same members as in the analysis of the standing railcar. The distribution along the length of the railcar is shown in Figure 13. The dashed vertical lines denote the locations of the body bolsters, and the periodic spikes seen in the stress data correspond to the location of the vertical and lateral framing members of the carbody. 


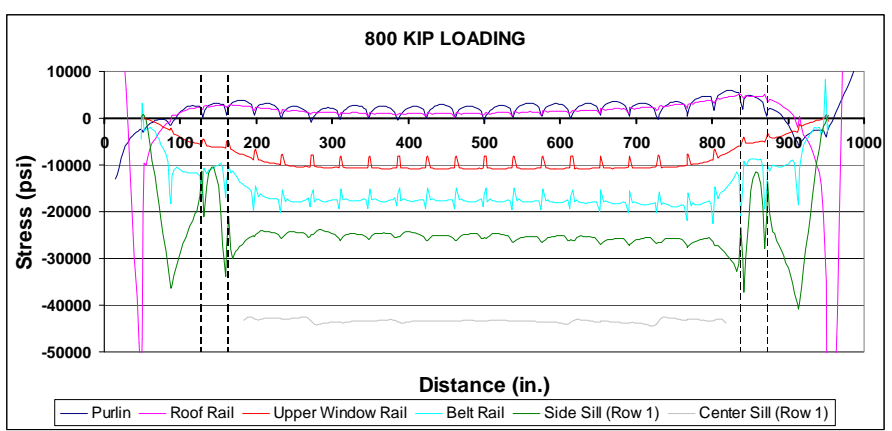

Figure 13 - Stress Distribution in Longitudinal Members, 800-kip Load

When subject to the 800-kip load at the buff stops, the carbody behaves like a single beam subject to a compressive load and a bending moment. The largest stress levels are seen in the center sill, which is along the centerline of the car and the lowest vertical member in the cross-section of the railcar.

Inboard of the body bolsters, the average stress level in the longitudinal members is compressive but decreasing for the side sill, belt rail, and upper window rail. The roof rail and purlin are both in a state of average tensile stress along their length. The average stress value for each member, determined over the occupant volume inboard of both body bolsters, is shown in Figure 14. Though the neutral axis was determined to be at a height between the belt rail and upper window rail, the transition from compression to tension is shifted vertically upward due to the presence of the compression portion of the 800-kip load.

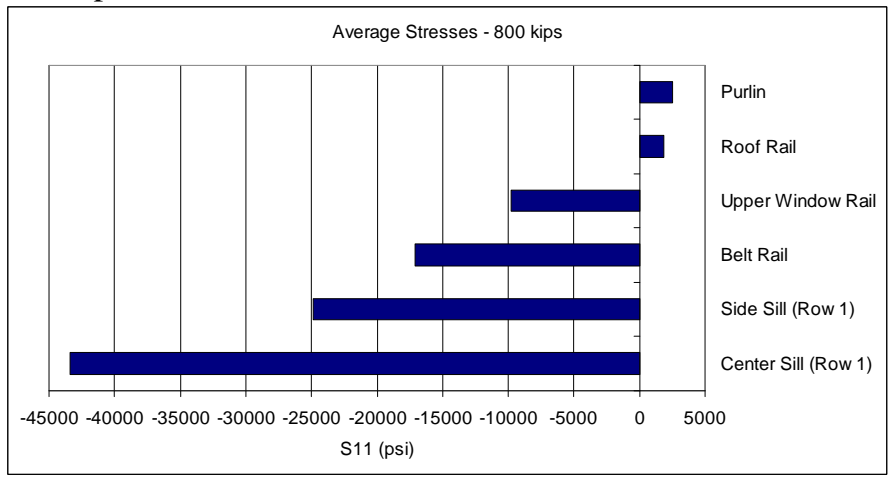

Figure 14 - Average Occupant Volume Stress, 800-kip Load

\section{Alternative Loading Tests}

Alternative loading cases were applied separately to the model, based on the results of the 800-kip compressive test. These loads consisted of 1 million lb distributed across the buffer beam, 200,000 lb distributed across the AT plate, and a combined 1.2 million lb distributed across the buffer beam and AT plate simultaneously. These alternative load cases are designed to test the entire occupant volume of the railcar for its compressive strength as well as resistance to a large bending moment.

\section{0-kip Compressive Test}

Based on the results of the 800 kip test, it was determined that any alternative test should maintain the rigor of a large compressive load and a significant bending moment applied to the carbody. In order to allow a wider variety of car design to be evaluated for compliance, it was desirable to shift the load application point away from the relatively small area of the buff stops.

The buffer beam was chosen as a candidate location to apply a floor-level compressive load. Unlike the buff stops, the buffer beam spans the entire width of the car. In a railcar with continuous side sills, this allows the load to be shared between those members and the center sill. The buffer beams are also located at the extreme ends of the superstructure, ensuring the entirety of the occupant volume is loaded by the proof load. Additionally, there is historical precedent for choosing the buffer beam as a load location, as 500-kip loads are recommended at this location for cars designed to both AAR S034 and APTA SS-C\&S-034-99.

Because the buffer beam is located above the draft sill and thus, the buff stops, it is closer to the effective neutral axis of the carbody. An 800-kip load applied across the buffer beam will result in a smaller bending moment than an 800-kip load applied at the buff stops. To account for this decrease in moment arm, the applied load was increased to 1000 kips. Unlike in previous buffer beam load cases, this load was distributed across the entire width of the member.

An FE simulation was run with the load applied as a pressure across the outboard face of the buffer beam. The load was reacted at the opposite end of the railcar by preventing longitudinal displacement of the outer face of that buffer beam.

The results of the 1000-kip load case were analyzed similarly to the results of the 800-kip case. The distribution of longitudinal stress along the length of the carbody is plotted in Figure 15. Similar to the 800-kip results (Figure 13), the center sill shows the largest magnitude compressive stress. The side sills are directly in the load path between buffer beams, which causes larger stresses in the 1000-kip side sills than in the 800kip side sills.

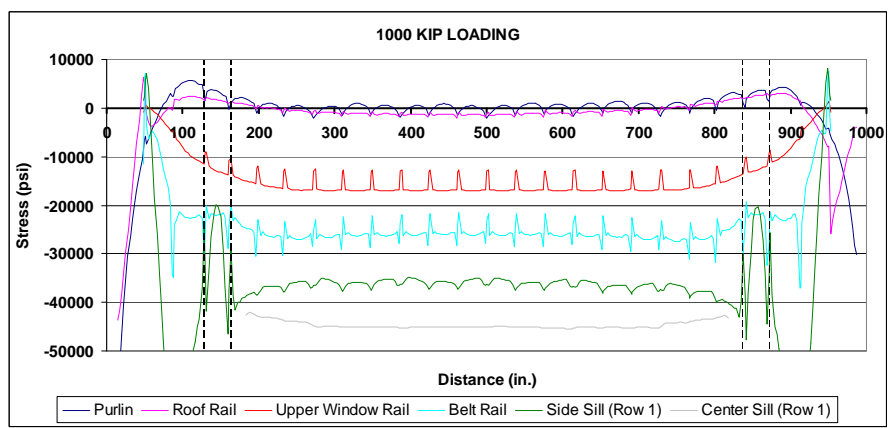

Figure 15 - Stress Distribution in Longitudinal Members, 1000-kip Load 
The average stress in each longitudinal member is plotted in Figure 16 for both the 1000-kip load case and the 800-kip conventional load case. Overall, the behaviors are similar, with a maximum compressive stress in the center sill that gradually transitions to a tensile stress state at the roof of the railcar.

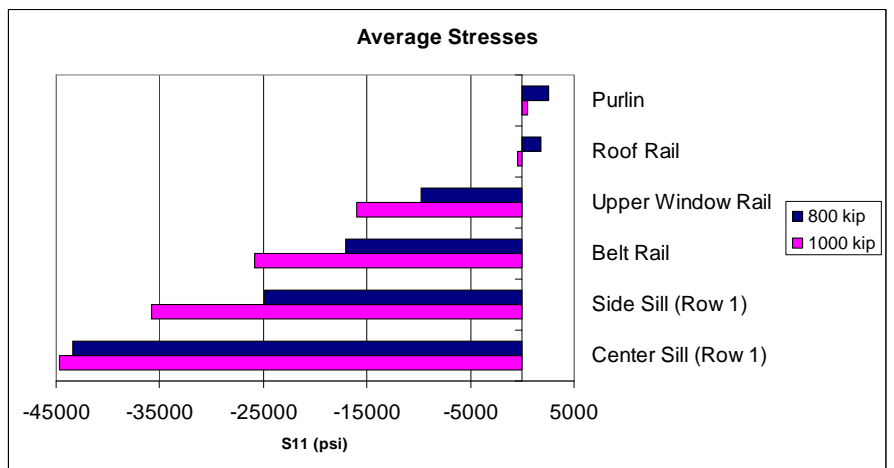

Figure 16 - Average Occupant Volume Stress, 800 and 1000 kip Loads

Because the 1000-kip load is distributed across the entire width of the car, the load path into the side sills is more direct than the 800-kip case. For members below the effective neutral axis, the compressive stress is a result of compression from bending as well as axial compression. For the upper members, the tensile stress from bending is acting against the compression of the axial force.

\section{Combined 1.2 Million-lb Test}

The second alternative loading setup consisted of adding a 200-kip compressive load to the AT plate while simultaneously loading the buffer beam with the $1000 \mathrm{kips}$, for a total load of 1.2 million $\mathrm{lb}$. This combined loading case places the largest compressive load across the endframe of the railcar. However, the 200-kip load is at a location above the effective neutral axis, while the 1000-kip load is below the neutral axis. This loading is expected to result in a partial cancellation of the moment generated by each distributed force.

Within the FE model, the loads were both applied as pressures. Boundary conditions preventing longitudinal motion were applied at the opposite end of the railcar, at the outer faces of the buffer beam and AT plate.

The stress distribution along the length of the railcar is plotted for the longitudinal structural members in Figure 17. The stress magnitudes throughout the occupant volume are more severely compressive under this loading than were seen under either the 800-kip load (Figure 13) or the 1000-kip load (Figure 15). This is attributed to the presence of 1200 kips distributed over the top and bottom lateral members of the endframe, which serves to place more longitudinal members directly into the load path.

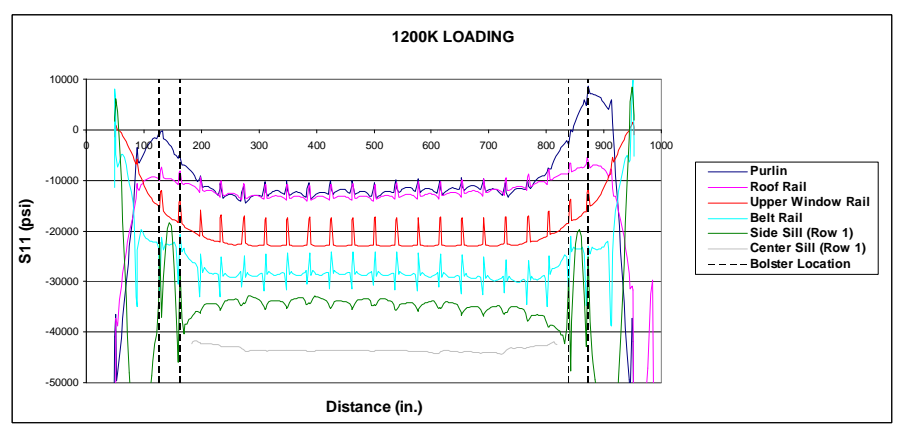

Figure 17 - Stress Distribution in Longitudinal Members, 1200 kip Load

A comparison of the average values of stress within the occupied volume for the 800-, 1000-, and 1200-kip loads is plotted in Figure 18. Unlike the 800- and 1000-kip loads, the 1200-kip load results in a compressive average stress in all members examined.

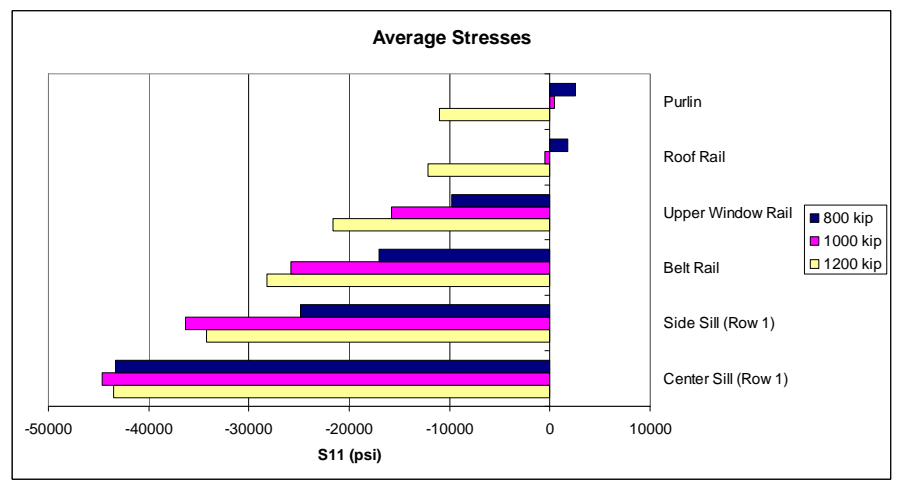

Figure 18 - Average Occupant Volume Stresses, 800-, 1000-, and 1200-kip Loads

While the 800- and 1000-kip loads both feature a single compressive load placed below the neutral axis of the railcar, the 1200-kip load also includes a 200- kip load at the roof level. This load places the roof-level members directly into compression. The compressive stresses from the 200-kip load exceed the tensile bending stresses generated in the roof members from the 1000-kip load below the neutral axis.

The magnitudes of the longitudinal stress in the underframe members under the 1200-kip load are slightly less than the stresses in the corresponding members under the 1000kip load alone. This can be attributed to the partial cancellation of bending moments caused by the 200-kip load on the opposing side of the neutral axis. Above the underframe, the combined stress state from the longitudinal loads and bending moments is such that the compressive stress from the 1200-kip load is greater than in either of the other load cases examined. As an intermediate loading condition, the 1000-kip load was omitted and the 200-kip load alone was placed at the AT plate. A full description of this load case, and its results, can be found in reference 11. 


\section{SUMMARY AND NEXT STEPS}

A FE model of a generic single-level passenger railcar has been developed for evaluation of static load cases. This model includes simplified member geometries, direct member-tomember connections, and linear elastic material, all in an effort to reduce the time needed to process a solution. The model exhibited single beam-like behavior, and the location of the neutral axis of the car was determined through analysis.

This model was subjected to the conventional 800,000-lb compressive load at the buff stops as an evaluation of its structural strength. Once the effects from this load on the carbody structure were understood, potential alternative loads were considered that would ensure similar structural strength of the rail vehicle without requiring specific structures be present in the underframe of the car.

The first alternative load considered was 1 million $\mathrm{lb}$ distributed across the buffer beam in the endframe of the railcar. This load places the car into a similar state of bending, with compression in the underframe and tension at the top of the roof.

The second alternative load examined maintained the 1 million $\mathrm{lb}$ buffer beam load and added 200,000 lb applied across the width of the AT plate, at the top of the endframe. This loading case resulted in an average compressive stress in all members examined along the length of the occupant volume.

The alternative loading cases examined demonstrate the possibility of performing compressive strength tests on locations in the railcar other than the buff stops while ensuring an equivalently strong railcar. By performing both the 1000and 1200-kip compression tests, the railcar is subjected to a large compressive and bending load reacted at the underframe, as well as a large compressive load spread across the entire endframe of the car.

Potential future work stemming from this research includes comparing the behavior of a detailed FE model of a single-level railcar with the simplified models used here. Once the modeling technique has been refined, it is important to validate the models used with full-scale testing. In this work, that would require performing a quasi-static compressive end strength test on a piece of conventional equipment. Both the conventional and alternative load cases should be tested to ensure satisfactory performance by both the model and the physical railcar. Examining the effects of the three load cases on a multilevel railcar is also desirable, to determine the applicability of the loads to a railcar with a transition in underframe height.

\section{ACKNOWLEDGEMENTS}

This work was done as part of the Federal Railroad Administration's Equipment Safety Research Program. The authors would like to thank Eloy Martinez, Program Manager, Federal Railroad Administration, for his helpful comments.

\section{REFERENCES}

[1] Tyrell, D., "U.S. Rail Equipment Crashworthiness Standards," Journal of Rail and Rapid Transit, Proceedings Part F, Institute of Mechanical Engineers, August 2002.

[2] U.S. Department of Transportation, Federal Railroad Administration, "49 CFR Part 216 et al., Passenger Equipment Safety Standards; Final Rule,” Federal Register, May 12, 1999. [3] Severson, K.J, "The Development of Collision Dynamics Models to Estimate the Results of Full-Scale Rail Vehicle Impact Tests.” Tufts University Master's Thesis, November 2000.

[4] White, J.H., "The American Passenger Railway Car," The John Hopkins University Press, 1978.

[5] Martinez, E., Tyrell, D., Perlman, A.B., "Development of Crash Energy Management Designs for Existing Passenger Rail Vehicles," American Society of Mechanical Engineers, Paper No. IMECE2004-61601, November 2004.

[6] Woodbury, Clifford A., "Design and Operation of Passenger Cars and Locomotives," The Car and Locomotive Cyclopedia, Simmons-Boardman Publishers, 1997 ed.

[7] Interstate Commerce Commission, "Report of the Director, Bureau of Safety. Accident on the Southern Pacific Railroad, Tortuga, California, September 20, 1938,” Investigation No. 2294, United States Government Printing Office, Washington D.C., 1939.

[8] Interstate Commerce Commission, "Chicago, Burlington \& Quincy Railroad Company Report in Regards to Accident at Naperville, IL, on April 26, 1946,” Investigation No. 2988. United States Government Printing Office, Washington D.C., 1946.

[9] Woodbury, Clifford A. "North American Passenger Equipment Crashworthiness: Past, Present, and Future,” Published in "Proceedings of the Symposium on Rail Vehicle Crashworthiness, June 1996", US Department of Transportation, DOT/FRA/ORD-97/08, 1998

[10] American Passenger Transportation Association, "APTA SS-C\&S-034-99, Rev. 2. Standard for the Design and Construction of Passenger Railroad Rolling Stock," June 15, 2006.

[11] Carolan, M. "Evaluation of Occupant Volume Strength in Conventional Passenger Railroad Equipment.” Tufts University Master's Thesis, May 2008.

[12] ABAQUS/CAE Version 6.6-1, 2006, Abaqus, Inc. Providence, RI, USA.

[13] Mayville, R., Stringfellow, R., Johnson, K., Tyrell, D., "Rail Vehicle Cab Car Collision and Corner Post Designs According to APTA S-034 Requirements,"American Society of Mechanical Engineers, Paper No. IMECE-2003-44114, November 2003.

[14] Stringfellow, R.G., Mayville, R.A., Rancatore, R., "A Numerical Evaluation of Protection Strategies for Railroad Cab Car Crashworthiness," American Society of Mechanical Engineers, AMD Vol. 237/BED Vol. 45, 1999. 